\title{
The untamed high mountain area of Hohe Tauern National Park
}

\section{Kristina Bauch \& Ferdinand Lainer}

keywords: Alps, Austria, Hohe Tauern, national park, Natura 2000, bearded vulture, glacier, virgin landscape, wilderness, biodiversity, Symposium on Research in Protected Areas, Nationalparks Austria, protected area management

\section{Abstract}

In Hohe Tavern National Park one of the last post-glacial virgin landscapes in the central Eastern Alps was designated as a protected area. It is the largest national park in Central Europe and includes a significant section of the Austrian Central Alps shaped by glaciers and glacial periods. Its highly diverse flora and fauna is representative for all altitudinal zones of the Eastern Alps. Two thirds of the total area of $1856 \mathrm{~km}^{2}$ are designated as core zone and represent a natural landscape almost totally free of human intervention. Hohe Tauern National Park was founded in Carinthia in 1981, in Salzburg in 1984 and in Tyrol in 1992.

\section{Profile}

Protected area

Hohe Tavern National Park

Mountain range

Alps

Country

Austria

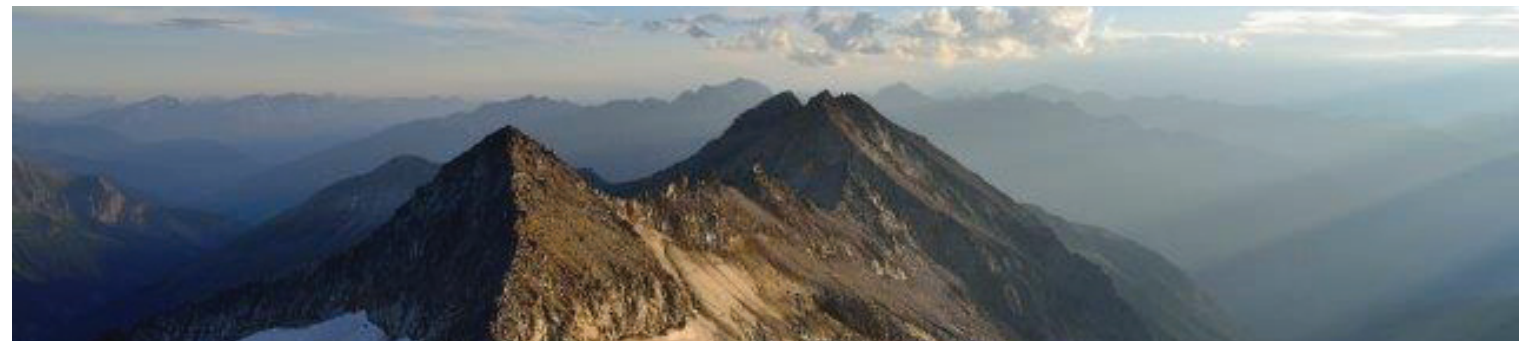

\section{An important part of Austria's natural heritage}

On a global scale, Austria is a very small country and yet, its territory is home to an extraordinarily diverse natural and cultural landscape. It shares in two of the eleven biogeographical regions of Europe, the alpine and the continental regions. In the east it borders on the Pannonian plain.

Such biogeographical diversity on the European scale is reflected in the six Austrian national park (NP) regions: the imposing, glaciated summits and untamed torrents of the Hohe Tauern; in the centre the rugged, dry, high plateaus and extensive forests of the Northern Limestone Alps; in the north and east the still intact Central European riparian woodlands along the Thaya and Danube rivers, and the wide steppes and salt lakes of the Seewinkel region. Unique, largely unadulterated natural landscapes have been conserved just in time and been put under a long-term and largescale protection against commercial exploitation, particularly for energy production.

All Austrian NPs have been recognized as IUCN Category II protected areas (PAs). Together they cover $2350 \mathrm{~km}^{2}$ or about $3 \%$ of the state territory. United under the label Nationalparks Austria (www.nationalparksaustria.at), they jointly work towards their main aim of making the Austrian population and govern- ment at all levels aware of the enormous significance of the large-scale maintenance of natural landscapes and ecosystems for future generations. Such sustained recognition is also sought internationally. To this end, the Austrian National Park Strategy was formalized in 2010 at policy level and the relevant authorities established. Since then the eight NP administrations, in cooperation with the relevant Federal Ministry of Agriculture, Forestry, Environment and Water Management, has developed and implemented joint activities and projects to realize this vision.

\section{A typical high mountain area}

The Hohe Tauern massif is a typical high mountain area and core element of the eastern part of the Alps in Central Europe. The character of the landscape has evolved through the temporal and spatial interaction of climatic, geological and geomorphological, glaciological and hydrological as well as through erosion processes.

The Hohe Tauern massif rises more than $3000 \mathrm{~m}$ above the adjacent area. The protected area includes Austria's highest summit, the Großglockner $(3798 \mathrm{~m})$; the largest contiguous glacier area in the Eastern Alps in the Venediger group of peaks and 266 other summits above $3000 \mathrm{~m}$, e. g. the Großvenediger $(3657 \mathrm{~m})$, the Hohe Sonnblick (3106 m) 


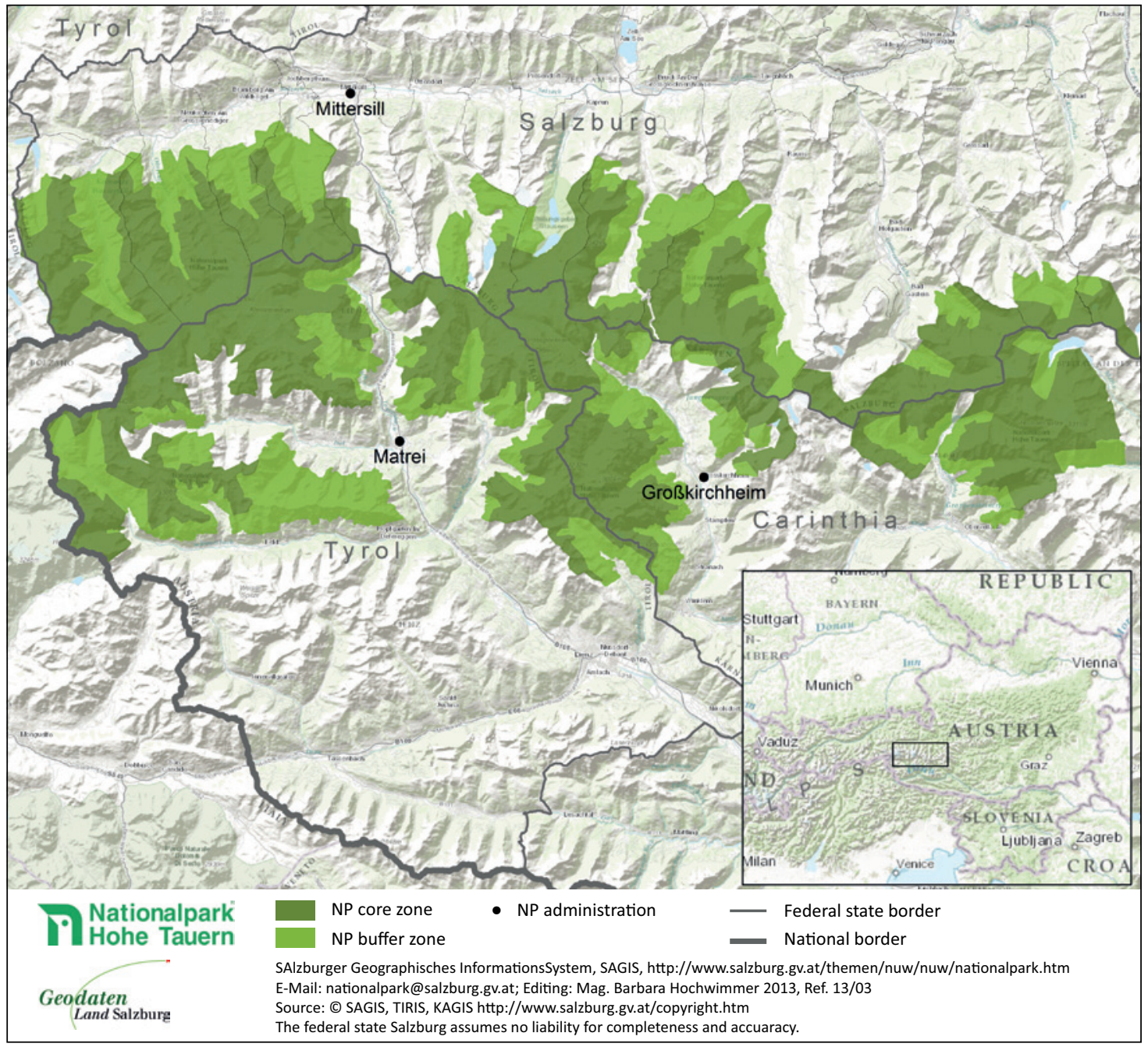

Figure 1 - Position and reach of Hohe Tauern NP in the federal lands of Carinthia, Saliburg and Tyrol.

and the Ankogel (3252 m). East to west it stretches across $100 \mathrm{~km}$, north to south across $40 \mathrm{~km}$. The altitudinal range starts at around $1000 \mathrm{~m}$ in the valleys to the highest summit at $3798 \mathrm{~m}$, see Figure 1 .

The enormous vertical range in the Hohe Tauern means that there are quite distinct zones: the typical climate for the region according to its latitude (warm temperate) and the vegetation and geomorphological forms linked to it changes with higher elevations. The ridges and summits jut out far beyond the natural treeline at 2200 to $2300 \mathrm{~m}$ (dependent on exposition) and a great number of erosion processes continue to shape the landscape.

\section{Geological window discovered}

Not until the early $20^{\text {th }}$ century, i.e. more than 150 years after the first geological studies in the area by Belsazar Hacquet, French geologist Pierre Termier noticed that the Hohe Tauern massif is the centre of a so-called geological window within the Austrian Central Alps. This discovery made it possible to explain the complicated structure of the Eastern Alps with reference to nappe tectonics, a model that had long been used to describe the structure of the Western Alps at the time.
The Tauern window stretches across $160 \mathrm{~km}$, from the Brenner groove in the west to the Katschberg groove in the east, with an average width of some $30 \mathrm{~km}$. The geological structure of this section of the Alps resembles that of an onion: the upper tectonic layers are missing and the lower strata of the earth's mantle crop out to the surface. The layers that initially covered them were pushed aside, mainly to the north and the south, during thrust and folding processes and today frame this geological window.

The rock series of the Tauern window stem from the Penninicum. The central gneiss core is made of the initially lowest layers of the penninic ocean and forms the base of the Venediger, Granatspitz and Ankogel summits. The gneiss cores are encased by a complicated structure of metamorphous rock series of different ages and formations, the so-called slate mantle. The Großglockner massif includes erosion-resistant greenschists, such as prasinites and amphibolites, which are the result of a metamorphosis of magmatic ocean crusts. They in turn are framed by East-Alpine layers that include the Northern Limestone Alps. 


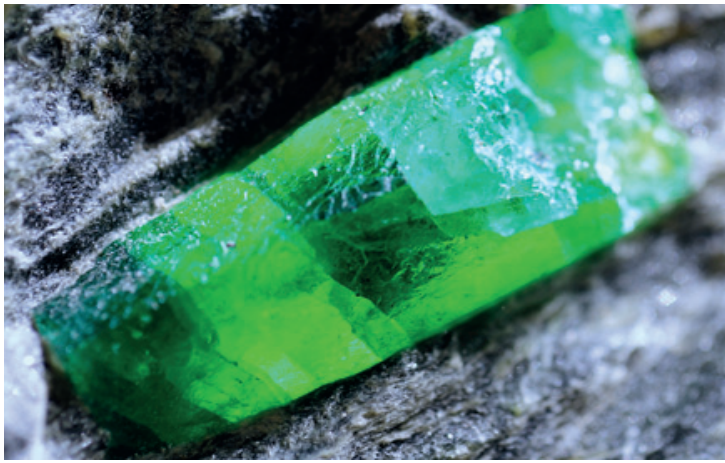

Figure 2 - The Habach emerald, which was discovered in the slate rocks of the Habach valley. (C) HTNP/F. Rieder

\section{Glistening and glittering treasury}

Another result of the transformation processes that physically and chemically changed all original rocks during the formation of the Alps was the emergence of so-called extension clefts, in which hot, saturated aqueous solutions circulated. The clefts formed when the bedrock expanded during the lifting of the massif. The wider extension clefts in particular have open cavities where the dissolved minerals could crystallize in an ideal-typical manner when pressure and temperature decreased during the lift. This process lasted several million years. Current thinking puts the age of the youngest cleft minerals at about five million years.

The Hohe Tauern area has been known for particularly beautiful crystal finds since prehistoric times. In addition to their value for science they have been entered into the mineral collections of natural history museums in many countries as prize exhibits. More than 150 different minerals have been identified in the NP area to date. Some are so small as to be hardly noticeable, others are up to a metre in size and weigh more than $600 \mathrm{~kg}$ (Figure 2).

Such hydrothermal processes also formed the many deposits of tungsten, arsenic, copper, silver and gold. From the Middle Ages into modern times, gold, silver and copper mining was a very significant economic factor in the Tauern region. The wealth of the Salzburg archbishopric, manifested in a number of magnificent buildings in the town, stemmed from salt mining but also from precious metal mining in the Hohe Tauern. In the NP today, only remnants of this once flourishing sector remain in the shape of dilapidated miners' houses and adits or slag heaps. The oldest records testify to copper mining in the Hohe Tauern as early as the Bronze Age, ca. 1800 BCE. The highest altitude at which mining took place in the Hohe Tauern was for gold and silver in the Glockner range at almost 2900 m, south-east of the Kloben summit (2936 m).

\section{Permanent nature workshop}

No sooner had the summits and ridges of the Hohe Tauern been lifted up that erosion set in through weathering and gravitational forces. Rock-

\section{Infobox}

\section{Hohe Tauern National Park}

Total area: $1856 \mathrm{~km}^{2}$

Total core zone: $1213 \mathrm{~km}^{2}$ (app. 2/3)

Total buffer zone: $643 \mathrm{~km}^{2}$ (app. 1/3)

\section{Carinthia}

Total area: $440 \mathrm{~km}^{2}$; Total core zone: $327 \mathrm{~km}^{2}$; Total buffer zone: $113 \mathrm{~km}^{2}$

Established: 1981; International IUCN recognition: 2001

Ownership: public: 1\%, private (individuals, municipalities): $84 \%$, private Alpine associations: $13 \%$, others: $2 \%$

7 NP municipalities: Großkirchheim (seat of the NP administration), Heiligenblut, Mörtschach, Winklern, Mallnitz (BIOS visitor centre), Obervellach, Malta

\section{Salzburg}

Total area: $805 \mathrm{~km}^{2}$; Total core zone: $539 \mathrm{~km}^{2}$; Total buffer zone: $266 \mathrm{~km}^{2}$ Established: 1984; International IUCN recognition: 2006

Ownership: public (Austrian Federal Forests AG): 35\%, private (individuals, municipalities): $59 \%$, private Alpine associations: $6 \%$, others: $0 \%$

13 NP municipalities: Mittersill (seat of the NP administration, NP Center Mittersill), Krimml, Wald im Pinzgau, Neukirchen, Bramberg, Hollersbach, Uttendorf, Kaprun, Fusch, Rauris, Bad Gastein, Hüttschlag, Muhr

\section{Tyrol}

Total area: $611 \mathrm{~km}^{2}$; Total core zone: $347 \mathrm{~km}^{2}$; Total buffer zone: 264 km² Established: 1992; International IUCN recognition: 2006

Ownership: public: $0 \%$, private (individuals, municipalities): $54 \%$, private Alpine associations: $46 \%$, others: $0 \%$

10 NP municipalities: Matrei i. O. (seat of the NP administration, Nationalparkhaus Matrei visitor centre), Prägraten, Virgen, St. Jakob im Defereggen, St. Veit im Defereggen, Hopfgarten, Kals am Großglockner, Nußdorf-Debant, Iselsberg, Dölsach

\section{Natural assets of Hohe Tauern NP}

Max. length west-east: 100 km; Max. length north-south: 40 km;

Altitudinal range: $1000 \mathrm{~m}$ to $3798 \mathrm{~m}$ (Großglockner), 266 summits above $3000 \mathrm{~m}$

Glaciated area: $170 \mathrm{~km}^{2}$ (app. 9\%)

Running waters: 1000 km, 279 natural torrents, of which 57 glacier-fed, 26 major waterfalls (Krimml waterfalls: $380 \mathrm{~m}$, hold the European Diploma of Protected Areas), 10 ravines

Lakes: 551, sizes from $35 \mathrm{~m}^{2}$ to 27 ha, max. depth $56.8 \mathrm{~m}$, at locations up to $2943 \mathrm{~m}$

Glaciers, rocks with and without vegetation, screes: $50 \%$

Alpine sedges (Carex curvula), alpine pasture (Nardus stricta) and dwarf shrub heaths (Vaccinium sp., Rhododendron ferrugineum, Juncus communis var. saxatilis): $36 \%$

Forest (Alnus incana, Picea abies, Larix decidua, Pinus cembra), green alder (Alnus viridis) and dwarf pine shrubland (Pinus mugo subsp. mugo): $11 \%$

Running and standing waters, infrastructure (e. g. alpine pasture huts, mountain huts): $3 \%$

(limestone) siliceous fens: 766 , total area $13.62 \mathrm{~km}^{2}$

Alpine alluvial areas (Carex bicolor, Carex atrofusca): 68, total size 285 ha

Characteristic fauna: bearded vulture (Gypaetus barbatus), griffon vulture (Gyps fulvus), golden eagle (Aquila chrysaetos), ptarmigan (Lagopus mutus), black grouse (Tetrao tetrix), Alpine ibex (Capra ibex), chamois (Rupicapra rupicapra), Alpine marmot (Marmota marmota) 

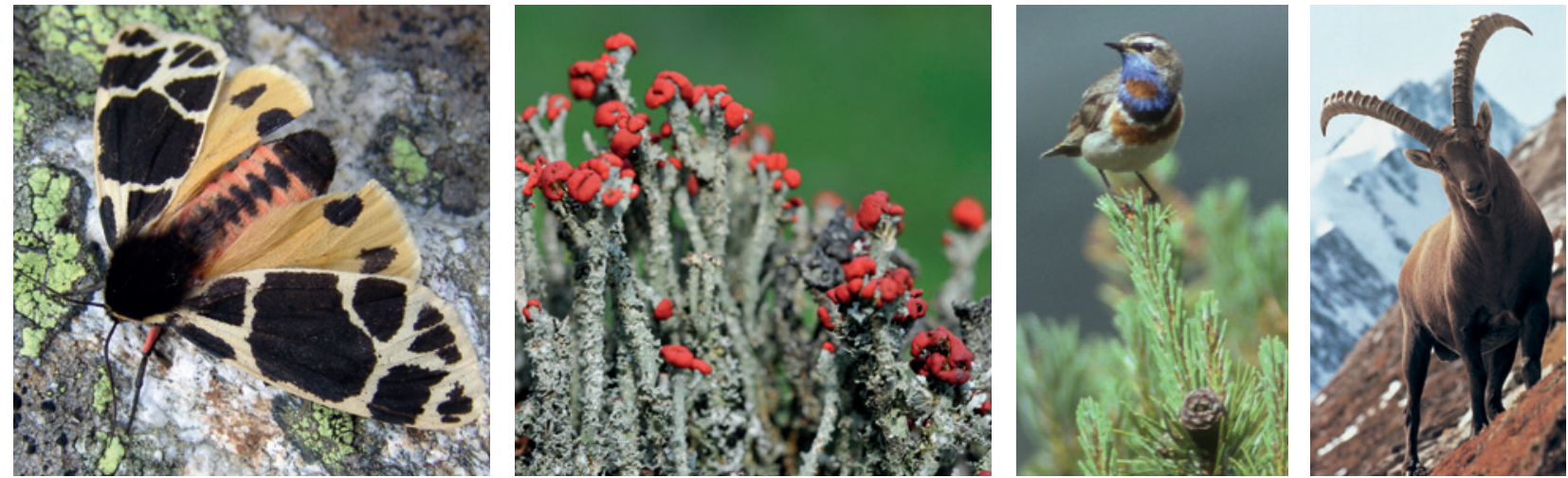

Figure 5 - A wealth of species in Hohe Tauern NP: 1296 butterfly species, here: yellow tiger moth, Arctia flavia (C) P. Gros. 1000 species of lichen, here: Cladonia sp. (C) HTNP / F. Rieder. 114 bird species, here: bluethroat, Luscinia svecica svecica. (C) HTNP / Carinthia. 52 mammal species, here: ibex, Capra ibex. (C) HTNP / Carinthia

HTNP includes all Central-Alpine habitats in sufficient size and in combination. It ensures not just the continuation of remnants of former natural landscapes, rather it maintains complete ecosystems with all their regulation mechanisms. The NP thus represents a significant portion of the characteristic landscapes and ecosystems, not just of Austria but of the Eastern Alps. Glaciers, rocks with and without plant cover, and screes make up around $50 \%$ of the NP area, ca. 36\% is alpine grassland (Carex curvula), mountain pastures (Nardus stricta) and dwarf shrubs (Vaccinium sp., Rhododendron ferrugineum, Juncus communis var. saxatilis), just over $11 \%$ are forests (Picea abies, Larix decidua, Pinus cembra) or green alder (Alnus viridis) and dwarf pine (Pinus mugo subsp. mugo) shrubland, the rest are running and stagnant bodies of water as well as infrastructure, e.g. various types of mountain huts.

The NP is home to about a third of all known ferns and flowering plants in Austria and a similar proportion of butterflies, dragonflies and grasshoppers. For fungi, lichens, mammals, birds, amphibians and reptiles, the proportion occurring in HTNP is nearer $50 \%$, rising to around two thirds for all known bumblebee and harvestmen species. For the numerous invertebrate groups we have only isolated, unverified or older evidence.
Today the NP also provides a long-term secure habitat for animal species that became extinguished across large parts of Europe in the early $19^{\text {th }}$ century, e. g. Alpine marmot (Marmota marmota), golden eagle (Aquila chrysaetos), ibex (Capra ibex) or the bearded vulture (Gypaetus barbatus).

More than half of the vertebrates occurring in HTNP are strictly protected by international conventions like the Fauna Flora Habitat Directive or the Birds Directive. About a third of these species are on the Red List of endangered animals in Austria. Large PAs like HTNP are thus proven significant retreats for species that are severely threatened across Europe.

\section{Establishing the national park}

Initial ideas of establishing a large PA in the Hohe Tauern were put forward at the beginning of the $20^{\text {th }}$ century. In 1913, Salzburg-based lawyer August Prinzinger organized donations for the purchase of 1100 ha land in the Stubach valley by the GermanAustrian Naturschutzpark association, with the aim of keeping this area free from human interventions. It took almost 60 more years before the governors of the federal lands of Carinthia, Salzburg and Tyrol signed the Heiligenblut Agreement in 1971, the first
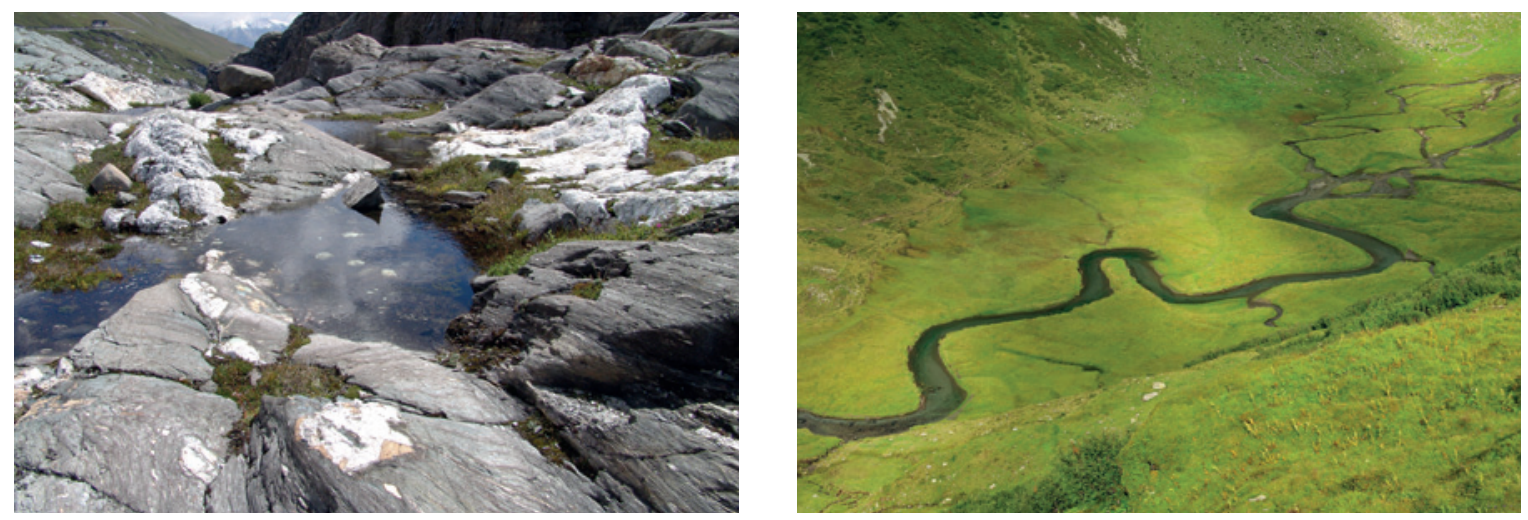

Figure 6 - The species diversity reflects the enormous diversity of habitats in the Hohe Tauern: left: a typical Alpine alluvial area with bicoloured sedge, Carex bicolor, and scorched Alpine sedge, C. atrofusca, in the Pasterze glacier forefield (C) NPHT / H. Wittmann. Right: Vordermoos, a typical fen in Hollersbach valley. (C) NPHT / F. Rieder 
formal basis for establishing a national park in the Hohe Tauern. It was at the time a conscious decision against the pressing interests of electricity producers and tourism actors who envisaged numerous large projects for hydro-electricity production and touristic development of the glacier regions for skiing in the Hohe Tauern. And yet these efforts were still miles away from the standards of an internationally recognized national park.

Plans for large hydro-electric power stations on both sides of the Hohe Tauern went on despite clear political signals to the contrary. The signing of the agreement was followed by years of laborious negotiations with the population and interest groups affected by the NP plans. Controversies centred on concerns that the NP would be detrimental to the economic development of the entire region. The spatial scale of the project and the range of themes and areas of activity that it touched, such as agriculture, hunting, forestry, tourism, energy production and infrastructure, as well as conservation and environmental protection, meant that there was an enormous number of stakeholders. The fact that three federal lands were involved made the situation even more complicated. Despite the NP commission being conceived as a cross-border body and acting as such, the different initial conditions in the three federal lands meant that from the start landspecific development paths were being pursued. All the same, the actors had to come together to work in partnership and find a consensus with all stakeholders for establishing a large NP. In this PA the conservation of the natural landscape should carry equal weight with the protection of centuries old extensively used cultural landscape.

Eventually the three federal lands passed the relevant legislation, Carinthia first in 1981, then Salzburg in 1983. In Tyrol it took until 1992 before the NP was realized along the aims formulated in 1971: "to maintain a particularly impressive and varied part of the Austrian Alps in its beauty and its native state for ever more, as the model of a representative Austrian landscape, for the benefit of the population and of science, and in support of the economy."

HTNP is the oldest and largest Austrian NP. The landscapes of the three separately administrated areas border on each other and form a contiguous area in the main range of the central Eastern Alps between the catchment areas of the rivers Isel, Möll, Salzach and Mur. The valleys opening to the north belong to Salzburg, those on the southern slopes to Carinthia and Tyrol. The total area of HTNP amounts to $1856 \mathrm{~km}^{2}$.

\section{Zoning}

A strict law that allowed no exceptions has protected the Hohe Tauern area against destruction by large developments. Achieving such protection against massive resistance and conflicting interests has rightly been celebrated as a significant success in spatial planning and conservation policy for Austria as a whole.
The aims of the NP, however, go far beyond preventing large developments. The NP regulations require the NP administrations to fulfil clear ecological and conservationist aims as manifested in the PA zoning enshrined in law. The three zones of HTNP differ in their natural assets, their conservation aims and their protective regulations:

\section{Core zone}

Around two thirds of the NP are designated as core zone and cover the unique natural landscape of the Hohe Tauern. This central protective zone covers summits and rugged peaks so typical for the Eastern Alps, glaciers and their forefields, natural alpine grassland, high mountain lakes, torrents and mountain forests. In the core zone of the NP nature protection has priority over all other aims. Here no intervention in the natural landscape and the ecosystems are allowed nor any impairment of the scenery. Exceptions are made for appropriate agri- and silvicultural activities as long as they are adapted to the natural conditions, hunting and fishing within the hunting and fishing regulations, as well as traditional walking and hiking tourism. The NP management ensures that natural dynamics and developments can occur here without human intervention.

\section{Buffer zone}

The buffer zone encapsulates the core zone and forms a transition to the permanently settled area outside the PA. This is where the typical Hohe Tauern cultural landscape is found, created and maintained by humans. It includes mountain pastures, traditional herdspeople's huts, wooden fences, dry-stone walled enclosures, mountain hay meadows and protective forests. Here, too, technical developments, for instance for energy production or extraction of raw materials, for ski tourism or public transport are prohibited. The priorities in the buffer zone are maintaining landscape characteristics, recreational aspects and diversity of habitats and species which depend on extensive grazing or mowing.

\section{Special conservation areas}

Areas of special ecological or landscape significance may be designated as special conservation areas by federal land directive, if the agreement of the affected land owners and holders of rights of use can be obtained. Special conservation areas are the strictest protection category in HTNP. To date five special conservation areas have been designated with a total area of $68 \mathrm{~km}^{2}$.

\section{National park region}

The permanently settled area of the so-called $\mathrm{Na}$ tional Park Region starts just outside the boundaries of the NP. It includes 35 municipalities with a total of some 93000 inhabitants. There are no villages or permanently lived-in settlements within the entire NP. 


\section{International recognition}

Unlike most other NPs across the world, HTNP was established mainly on private property in the middle of the vibrant and densely settled economic region of Central Europe. It was neither desired nor possible to pass a law stopping the rights of use linked in Austria to land ownership, such as grazing and wood exploitation or hunting rights, as this would have been equivalent to expropriation. In consequence, the IUCN did not acknowledge HTNP immediately as a Category II PA once it had been established.

As early as 1986, shortly after the Salzburg part of the NP had been designated, an IUCN delegation travelled through the Carinthian and Salzburg sections of the NP. The experts admired and acknowledged the efforts made to safeguard this natural and cultural landscape, to disseminate the NP concept and to integrate the municipalities and the local population. And yet, the delegation did not put the areas in Category II for NPs, where the priority is on protecting ecosystems and processes, but in Category V for Protected Landscapes. At that time the extent of agriculture, forestry and hunting in the core zone was inadequately determined.

Not until 15 years later could the path be cleared for international recognition. It took years of negotiation and some financial compensation throughout much of the core and some of the buffer zones to obtain contractual agreements with the owners to abandon hunting in particular. Carinthia reached this goal in 2001, Salzburg and Tyrol followed in 2006.

\section{Organization and administration}

Given its origin and framework conditions, the organizational structure of HTNP is comparatively complex. To enable it to fulfil its many and varied tasks, the necessary decision-making and advisory bodies and fields of activity were created in the three administrations. At the core of the agenda are the operational areas natural space management, science and research, and education and visitor information. In full awareness of the fact that HTNP is embedded in a region where people work, live and do business, the NP administrations also substantially support the maintenance of the cultural landscape, regional development and the creation of appropriate attractions for tourism.

\section{An association of PAs in law and in fact}

The distribution of responsibilities between the national and the federal land level is set down in the Austrian federal constitution. It contains a general clause in favour of the federal lands, which puts conservation, and hence NPs, in legislation and execution within the autonomous realm of the nine federal lands. Austria thus has no national conservation nor a nation-wide national park law or basic federal laws as in Germany.
For HTNP this means that it is de facto an association of three independently established and run NP administrations, both in law and in organization, with separate decision-making bodies, administrative hierarchies, staff and budgets. In an effort to enable cooperation across PAs and federal lands within this framework, an inner-Austrian state treaty was signed in 1994, which also formally integrated the national level, as the republic provides national funds in addition to the federal land funds. At the political level, the NP Council was created and at the operative level the NP directorate, supported by the Council Office.

While the administrations of the other Austrian NPs were established as limited companies, the three administrations of HTNP, for historical reasons, are made up of different organizational units: the NP directors and some of their staff are civil servants of the relevant federal land, others are employees of the relevant NP fund. All employees are also engaged in the business activities of their respective NP fund, regardless of employment status. The NP Act in Salzburg has one peculiarity in that the NP administration takes on the sovereign power for executing it as first judicial authority for the core zone and as second-level authority for the buffer zone. In the other two federal lands the execution of the NP Acts is the responsibility of the respective district administration.

\section{Natural space management}

The central aim of an internationally recognized Category II NP is a natural environment free from human intervention. To this end, two thirds of the core

\section{Infobox}

\section{Contact}

Hohe Tavern National Park

www.hohetavern.at

Nationalparkverwaltung Kärnten

Döllach 14, 9843 Großkirchheim, Carinthia, Austria

Tel.: 0043 (0) 48256161 - 0, Fax: 0043 (0) 48256161 - 16

nationalpark@ktn.gv.at

Nationalparkverwaltung Salzburg

Gerlos Straße 18, 5730 Mittersill, Salzburg, Austria

Tel.: 0043 (0) 656240849 - 0, Fax: 0043 (0) 656240849 - 40

nationalpark@salzburg.gv.at

Nationalparkverwaltung Tirol

Kirchplatz 2, 9971 Matrei i. O., Tyrol, Austria

Tel.: 0043 (0) 48755161 - 0, Fax: 0043 (0) 48755161 - 20

nationalparkservice.tirol@hohetavern.at

Education and visitor offerings:

www.nationalparkerlebnis.at

www.hohetavern.at/de/bildung/bildungsprogramme.html 

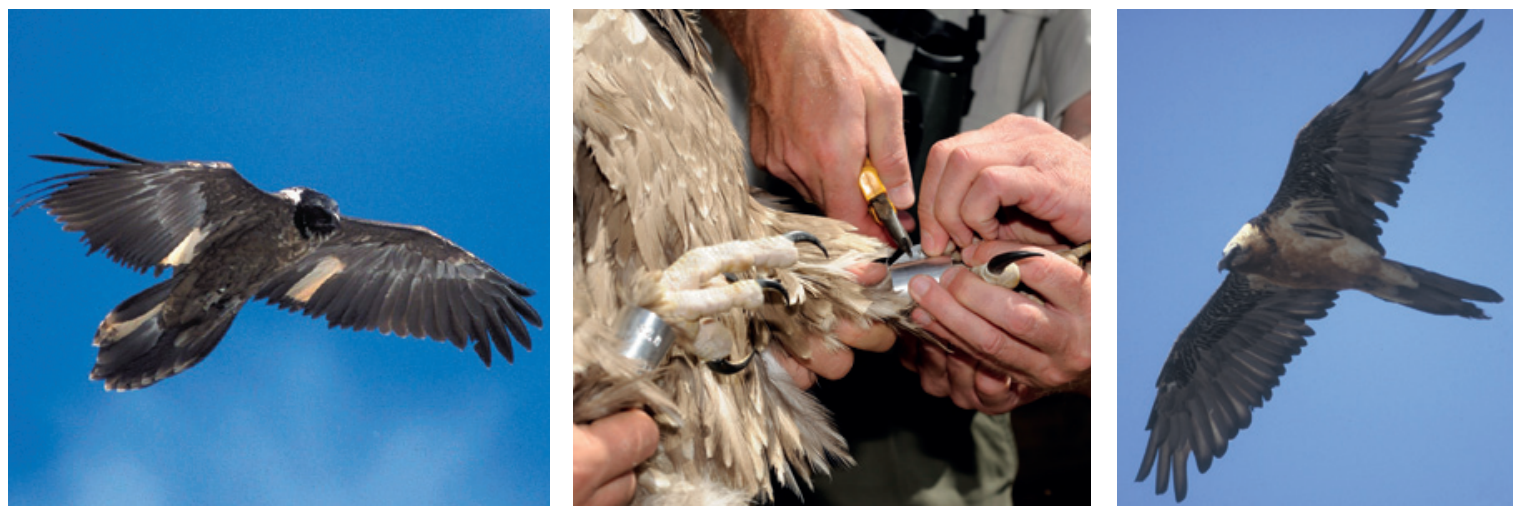

Figure 7 - The released bearded vultures are marked with bleached feathers (far left: young bird) and colour-coded rings and wear a satellite sender to monitor the daily position of the young birds (far right: adult bird). The positions can be called up on www. hohetauern.at under Bartgeier online. (C) NPHT / M. Knollseisen

zone area of HTNP were taken out of use by means of contractual conservation. The ownership structure of the NP, with more than 1000 private land owners, means that this path of negotiation, at eye level and on the basis of voluntary participation, is timeconsuming and involved, but is the only expedient strategy alongside official conservation. Many years of experience in HTNP have confirmed that the decisive factors for sustained success in NP management are trusting cooperation with all affected interest groups and an appropriate compensation for reduced rights.

The NP Act by no means repeals all other regulations. The national laws on forests, water and the environment remain in force for the $\mathrm{PA}$, as do the federal land laws on hunting and fishing, and the path allowance in the mountains, which allows access to unused land. In addition, the three parts of the NP have been nominated as Natura 2000 areas according to the Flora Fauna Habitat Directive and the Birds Directive.

\section{Science and research}

Research in the Hohe Tauern has a long tradition. Even more than 200 years ago, the spectacular but rather inaccessible high mountain scenery stimulated universal scholars such as Franz Xaver von Wulfen (botanist and mineralogist), Sigismund von Hohenwart (butterfly expert and botanist) or David Heinrich Hoppe (physician and botanist) to pioneering achievements, both in mountaineering and in research terms. The Großglockner summit particular attracted natural scientists of the time who ventured into the inner mountains on some daring expeditions.

Another important period in Alpine research in the Hohe Tauern was started in the mid- $19^{\text {th }}$ century by the brothers Adolph and Hermann Schlagintweit, who measured the Pasterze glacier for the first time in 1864. Since then the Pasterze has been measured at regular intervals. The collected data represent the longest continuous time series in the world on any glacier. In 1886 the Austrian Julius Ferdinand von Hann, who established modern meteorology, initiated the construction of an observatory on the Hohe Sonnblick peak, with the support of mine owner Ignaz Rojacher from Rauris. At $3106 \mathrm{~m}$ elevation, it is the highest located observatory in the world that is manned all year, far away from any sources of emissions, and possesses a highly valuable continuous climate data series dating back to a period when such data were not automatically recorded and saved.

In the early days of systematic natural sciences, the focus was on discovery and qualitative description of animate and inanimate nature. Once HTNP had been established, research increasingly turned towards the role of ecological processes and changes, e.g. climate change, reduced high mountain grazing, human impact, as well as towards long-term, standardized monitoring. Scientific monitoring of the resettlement of the bearded vulture (Gypaetus barbatus) in the Alps is an important practical example. This international species protection project to return a characteristic species, which had become extinguished across the Alps in the early $20^{\text {th }}$ century, was a pioneering achievement started in 1986 in the Rauris Kruml valley in HTNP. By 2013, 197 bearded vultures had been released into the wild across the Alps, 55 young birds in HTNP alone. In addition, 109 young birds have successfully hatched in the wild to date. Such a species protection project would not have been possible without the national parks as large PAs and stepping stones in a cross-border ecological network with an administration that is capable of applying the necessary expertise in natural landscape management, research and PR in a focused way (Figure 7).

Today the Hohe Tauern are an internationally recognized large PA and research as a function of the PA management is enshrined in law. The NP administration takes on the coordination and control of thirdparty funded research, contract research and NP-initiated research, all of it on the basis of the NP research concept. The two PA categories NP and Natura 2000 provide the spatial and temporal framework for the Hohe Tauern to act as a reference area and dynamic research space for international research.

The NP ensures the required high quality of the research activities through cooperations with research 


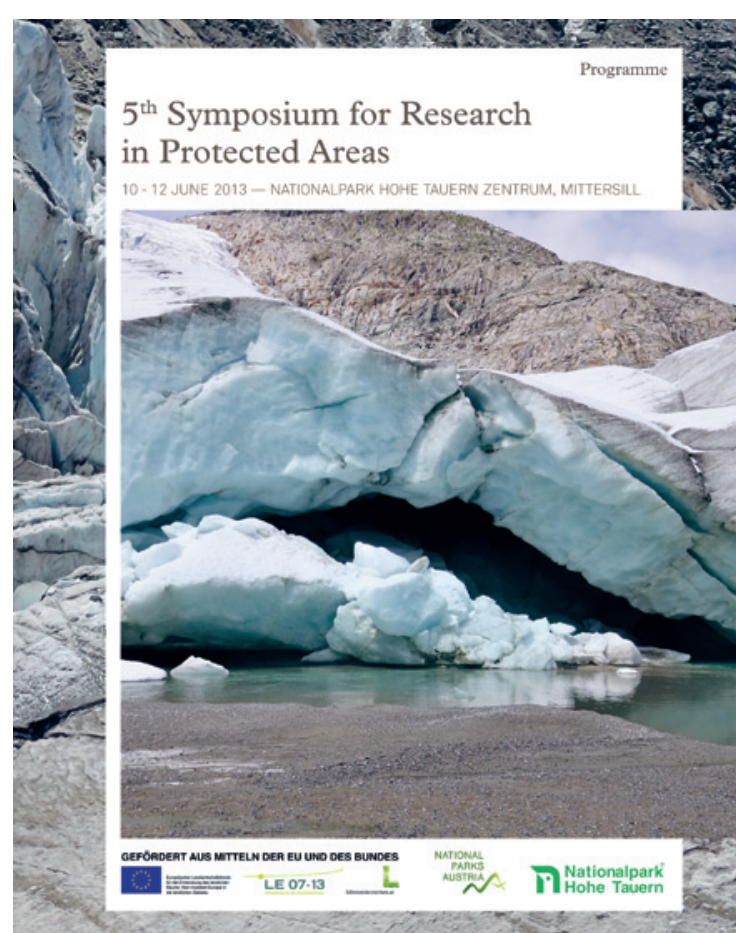

Figure 8 - The $5^{\text {th }}$ Symposium provided an international and interdisciplinary overview of basic, long-term and applied research in PAs on biodiversity, bydrology, cryosphere, PA management and sustainable development.

institutions like the University of Innsbruck or the Biodiversity Centre at the Haus der Natur, Salzburg, through consultation with experts of the international Scientific Advisory Council, through involvement in networks like ALPARC (Network of Alpine Protected Areas) and Nationalparks Austria and through regularly hosting the International Symposium on Research in Protected Areas. In 2013 the $5^{\text {th }}$ such event was held in Mittersill, Salzburg, and attracted nearly 300 participants (Figure 8).

\section{Education and visitor information}

HTNP, with its diverse natural space, good visitor infrastructure and specially trained staff, has the perfect prerequisites for a high-quality education and information programme, which aims to raise awareness of conservation and understanding for the NP concept and the PA itself in all its interacting elements. It does this by targeting information to specific visitor groups and providing them with an insightful experience. HTNP bases its efforts on the formula experience + information $=$ awareness of one's actions and endeavours to adapt its offerings regularly to the latest educational and didactic thinking. Not authoritarian, anti-modern environmental education and instruction, instead the NP aims to leverage people's curiosity and thirst for knowledge, as it arises when they experience nature, to achieve the NP's educational and dissemination objectives.

The education and visitor options are every bit as extensive and diverse as the NP region and the PA itself and cannot be described here in detail. There are four large visitor information centres, one each in Mittersill, Mallnitz, Matrei and on Franz-Josefs-Höhe at the Großglockner High Alpine Road (Figure 9). They attract visitors from at home and abroad with large-scale, interactive permanent exhibitions. Nearly 20 themed exhibitions in other National Park Region municipalities, a wealth of guided nature excursions in summer and winter, plus themed paths in the area complement the range of visitor options. For schools there are additional themed indoor programmes in the NP Workshop in Hollersbach, at the NP Science Centre in Mittersill, at the BIOS NP Centre in Mallnitz and in the House of Water in St. Jakob im Defereggen, as well as the mobile water and climate school, which have been noted and admired far beyond the boundaries of HTNP. Groups of school kids from other federal lands in Austria and from neighbouring Bavaria in Germany come into the NP regions for NP projects. For adult education and teacher training, the NP has established the NP Academy.

\section{Outlook}

Recently a scientific study was completed on the topic 100 Years of NP concept in the Hohe Tauern. This first thorough academic exploration of the NP's history provides insights into the multifaceted debates about the protection and use of this large Alpine area, alongside a discourse about the relationship between humans and nature as reflected in the contemporary society of each period.

Neither nature nor the NP concept or NP management are static categories. International conservation policy, too, is dynamic and alive. This means that today initiatives are coming to the fore which focus on process-oriented conservation of large wilderness areas. NP Hohe Tauern does not want to dismiss such concepts and will expand its current aims by developing and designating wilderness areas as defined by the Wild Europe Initiative.
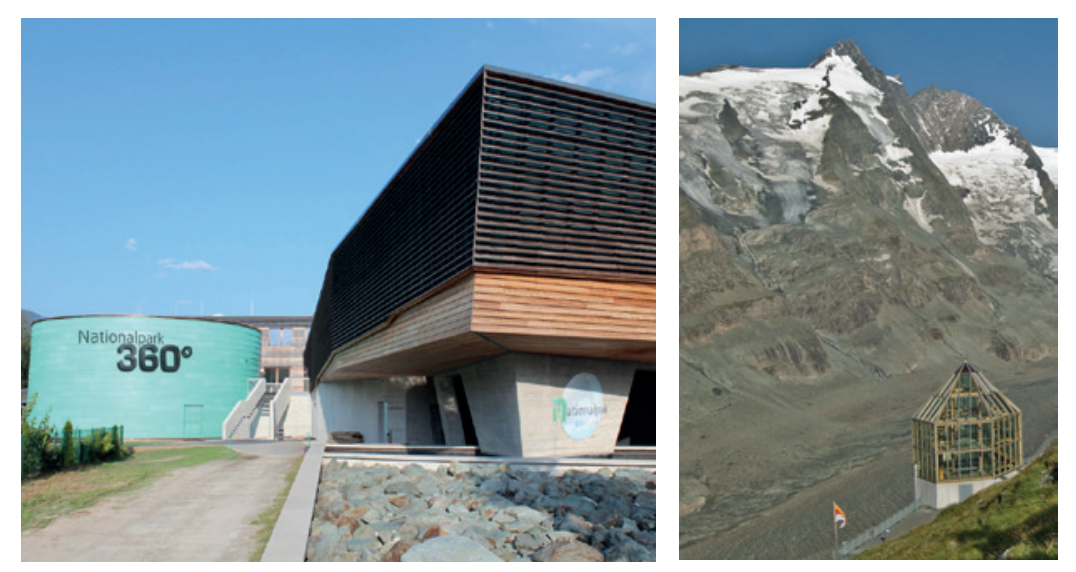

Figure 9-Education and visitor information material and programmes are constantly being adapted and targeted at the different visitor groups: National Park Science Centre in Mittersill. C NPHT / Salzburg. The Wilhelm Swarovski Observation Point opposite the Großglockner. (C) K. Dapra 


\section{References}

Bauch, K., M. Jungmeier \& S. Lieb 2007. Forschungskonzept Nationalpark Hohe Tauern 2020. Matrei i.O.

Bauch, K. (ed.) 2013. $5^{\text {th }}$ Symposium for Research in Protected Areas. Conference Volume. Mittersill.

Bundesministerium für Land- und Forstwirtschaft, Umwelt und Wasserwirtschaft (ed.) 2010. Österreichische Nationalpark-Strategie. Ziele und Visionen von Nationalparks Austria. Wien.

Floimair, R. (ed.) 1989. Salzburger Nationalpark Report. Schriftenreihe des Landespressebüros. Serie Salzburg Informationen 69. Salzburg.

Floimair, R. (ed.) 1994. Umdenken. Zehn Jahre Nationalpark Hohe Tauern in Salzburg - eine Bestandsaufnahme. Schriftenreihe des Landespressebüros. Serie Salžburg Diskussionen 19. Salzburg.

Füreder, L. 2007. Nationalpark Hohe Tauern Gewässer. Wissenschaftliche Schriften des Nationalparks Hohe Tauern. Innsbruck.

Hartl, H. \& T. Peer 2005. Nationalpark Hohe TauernPflanzen. Wissenschaftliche Schriften des Nationalparks Hohe Tauern. Klagenfurt.

Huemer, P. \& C. Wieser 2008. Nationalpark Hohe Tauern - Schmetterlinge. Wissenschaftliche Schriften des Nationalparks Hohe Tauern. Innsbruck.

Kärntner Nationalparkfonds Hohe Tauern (ed.) 2011. 30 Jahre Nationalpark Hohe Tauern Kärnten. Kärntner Nationalparkschriften 13. Großkirchheim.

Krainer, K. 1994. Die Geologie der Hohen Tauern. Wissenschaftliche Schriften des Nationalparks Hohe Tauern. Klagenfurt.

Kupper, P. \& A.-K. Wöbse 2013. Geschichte des Nationalparks Hohe Tauern. Wissenschaftliche Schriften des Nationalparks Hohe Tauern. Innsbruck.

Lieb G.K. \& H. Slupetzky 2011. Die Pasterze. Der Gletscher am Großglockner. Salzburg.

Salzburger Nationalparkfonds Hohe Tauern (ed.) 2012. Tätigkeitsbericht 2012. Mittersill.

Salzburger Nationalparkfonds Hohe Tauern (ed.) 1996. Der Bartgeier und seine Heimkehr in die Alpen. Ein internationales Artenschutzprojekt. Neukirchen am Grv.

Stüber, E. \& N. Winding 2007. Die Tierwelt der Hohen Tauern - Wirbeltiere. Wissenschaftliche Schriften des Nationalparks Hohe Tauern. Innsbruck.

Wittmann, H., O. Stöhr, R. Krisai, S. Gewolf, S. Frühwirth, Th. Rücker \& W. Dämon 2007a. Erfassung der Moore im Nationalpark. Hobe Tauern in den Bundesländern Kärnten, Salzburg und Tirol. Pflanzensoziologische und standortökologische Untersuchung der Moore des NPHT. Unveröffentlichte Studie im Auftrag des Nationalparks Hohe Tauern.

Wittmann, H., O. Stöhr, R. Krisai, S. Gewolf, S. Frühwirth, Th. Rücker \& W. Dämon 2007b. Vollerfassung und Dokumentation der alpinen Schwemmländer mit Pionierformationen des Caricion bicoloris-atrofuscae im Nationalpark Hohe Tauern. Unveröffentlichte Studie im Auftrag des Nationalparks Hohe Tauern.
Wittmann, H., Th. Rücker, R. Lindner, P. Gros, O. Stöhr, Ch. Medicus, K. Bauch, F. Jurgeit \& K. Aichhorn 2010. Vielfältiges Leben. Biodiversität in den Hohen Tauern. Matrei i.O.

BGB1. Nr. 570/1994: Vereinbarung gemäß Art. 15 a B-VG zwischen dem Bund und den Ländern Kärnten, Salzburg und Tirol über die Zusammenarbeit in Angelegenheiten des Schutzes und der Förderung des Nationalparks Hohe Tauern.

LGB1. Nr. 108/1971 i.d.g.F.: Kundmachung der Salzburger Landesregierung vom 19. November 1971, mit der die zwischen den Ländern Kärnten, Salaburg und Tirol getroffene Vereinbarung über die Schaffung des Nationalparks Hobe Tauern verlautbart wird.

LGB1 Nr 55/1983 i.d.g.F.: Gesetz über die Errichtung von Nationalparks- und Biosphärenparks (Kärntner Nationalpark- und Biosphärenparkgesetz - K-NBG).

LGBl. Nr. 106/1983 i.d.g.F.: Gesetz vom 19. Oktober 1983 über die Errichtung des Nationalparks Hohe Tauern im Land Salzburg.

LGBl. Nr. 103/1991 i.d.g.F.: Gesetz vom 9. Oktober 1991 über die Errichtung des Nationalparks Hohe Tauern in Tirol (Tiroler Nationalparkgesetz Hohe Tauern).

\section{Authors}

\section{Kristina Bauch}

Born 1967. Holds a diploma in botanics and vegetation science from the University of Salzburg. Internship at the Federal Agency for Nature Conservation, Bonn, Germany. Further studies at the University of Bergen, Norway. Started work at HTNP Salzburg administration in October 1994. Responsible for coordinating science and research and Natura 2000 issues. Organizer of the international symposia on research in PAs since 1996. Member of the ALPARC - ISCAR-P Scientific Board and the Editorial Board of eco.mont since 2008. Head of the Scientific Advisory Coucil of HTNP in Carinthia, Salzburg and Tyrol since 2011. Contact: kristina.bauch@salzburg.gv.at

\section{Ferdinand Lainer}

Born 1959. Studied forestry at the University of Natural Resources and Life Sciences, Vienna. State exam in forestry. Worked at the Styrian Chamber of Agriculture and Forestry from February 1985 to November 1987, responsible for silvicultural support, the energy forest programme and forest road / farmstead access in the Upper Mur valley. Started work at HTNP Salzburg administration in November 1987. Responsible for natural space management; surveyor for authority procedures and conservation expert for the Salzburg NP region. Heads the international species protection project to reintroduce the bearded vulture in the Hohe Tauern. Contact: ferdinand.lainer@salzburg.gv.at

Nationalparkverwaltung Hothe Tauern Salzburg, Gerlos Straße 18, 5730 Mittersill, Austria, Tel.: 0043 (0) $656240849-0$ 